\title{
Techniques of Optimizing Whatsapp as an Instructional Tool for Teaching EFL Writing in Indonesian Senior High Schools
}

\author{
Ani Susanti, Ali Tarmuji
}

Ahmad Dahlan University, Indonesia

\begin{abstract}
Studies reported that Whats Apps is effective to enhance the students' language skills, motivation and rapport especially to adolescent learners. The typical characteristics of adolescent learners challenge teachers to find strategies to engage them. One of the strategies is through mobile learning. This paper shares three techniques of writing activities to help adolescent learners develop their text types writing ability using WhatsApp. The techniques are brainstorming - group drafting - teacher's feedback, starter - quick writing peer feedback, and information gathering - elaboration exercises - checklist.
\end{abstract}

Keywords: mobile learning, EFL writing, text types, whatsapp

\section{INTRODUCTION}

The development of technology has influenced all field of life. In the education field, the teaching and learning is growing from traditional face to face instruction in the real classroom into long distance instruction in a virtual classroom. Most of schools and other learning institutions accommodate the growth of technology by making use of computers, tablets, and smartphones. Mobile learning is considered as a future trend which facilitates lifelong education where learning can be anywhere and everywhere (Khubyari, 2016).

The recent studies on Mobile Assisted Language Learning (MALL) report that mobile instruction is effective to improve the high school students' motivation to learn English (Danesh and Amiri, 2015), to build rapport between students and teachers (Khubyari, 2016), and to develop students' language skills (Fattah, 2015; Hazaea and Alzubi, 2016; Mistar, 2016).

Considering the effectiveness of mobile learning for English language classroom, it is interesting to dig the potentials of using the most popular instant messenger (WhatsApp) in English skills teaching. While mobile technologies are mostly suitable for listening, speaking, and reading skills, it is also worthy to explore the optimization of mobile technology especially for teaching and learning writing skills (Sussex, 2012: 221).

This paper explores the possible techniques in optimizing the application of WhatsApps for teaching English writing in Indonesian senior high schools.

\section{LITERATURE REVIEW}

\subsection{Studies on WhatsApp is EFL Classroom}

WhatsApp is popular instant massaging applicable for various devices and gadgets. It was invented by Jan Koum and Brian Acton in 2009, starts booming since 2010 and used by more that 350 millions users in 2013 (Cohavi, 2013). The users may increase in the last three years up to 2016. This free of charge application is favored by the marketbecause of the flexibility and useful features to text, to call, and to send video, audio, links, location, document, pictures.

EFL learning institutions are recently interested to use WhatsApp as an instructional tool to develop students' language skills and motivation. Fatah (2015) reports his experimental study on the use of WhatsApp messenger to develop students' writing skills. A group WhatsApp named "Writing Program" had six days writing process where the first day the students experience pre-writing step to generate ideas for choosing a topic in the WhatsApp group. In the second day, the students brainstorm ideas and start drafting. In the third day the students review and conducted peer correction. In the 
fourth and fifth day the students edit their draft in the WhatsApp. Finally, the students publish their draft in the sixth day. The findings of this study report that there's a significant improvement on the students writing quality. The students felt free to express their ideas and felt happy to correct and edit their peer works.

WhatsApp helps the students to learn language better and enhances their English proficiency; the use of WhatsApp should be encouraged to improve the collaboration between high and low achievers students (Mistar, 2016). The flexibility of WhatsApp is potential to bridge the diverse of learning needs through circular writing (Fatah, 2015) and collaborative writing. The students work together in a group to produce a piece of writing. (Harmer, 2007: 270).

Another experimental study reported by Khubyari (2016) shows the impact of MALL in EFL learners' classroom rapport. The experimental groups were intermediate level adolescents' female students. The researcher treated the students similar during the course by sending them the course content and practice through mobile phone. The researcher provided mobile phones during the study for students who did not have personal mobile phone. This study did not specifically mention the application name used for sending text messages to the students. The finding shares that regular and immediate text messages can establish rapport between the teacher and the students. The idea of sending regular and immediate text is applicable and possible to whatsApp. Harmer (2007: 25) writes that students' intrinsic motivation depends on their perception of what teacher thinks and treats them; good rapport between teachers and students can bring the positive, enjoyable, and respectful relationship.

\subsection{Mobile Assisted Language Learning}

Kukulska-Hulme \& Shield (2008) defines MALL as "formal and informal learning mediated via handled devices which are potentially available for use of anytime, anywhere" Language learners who used their devicessuch as phones, tablets, electronic dictionaries, MP3 Players, and gaming devices to study autonomously improve their language skills (Kukulska-Hulme \& Shield, 2008).

Review on MALL presents that mobile learning has both advantages and challenges. Mobile learning facilitates social interaction, data exchanging and collaboration with other learners (Chinnery, 2006). Sa'aleek (2014) summarizes that mobile technology effectively enhance the language skills due to the features such as accessibility, interactivity, immediacy, and permanency. However, MALL also has challenges such as reduced screen sized, limited audiovisual quality, virtual keyboarding and one finger data entry, and limited power (Chinnery, 2006).

\subsection{EFL Adolescent and Intermediate Learners}

High schools students are adolescent learners which have typical characteristics. Harmer (2007: 15) briefly explains that adolescent learners start to talk about more abstract ideas and accept the need for learning of a more intellectual type; they have potential for creative thought and passionate to things which interest them. In many senior high schools, their English language proficiency belongs to intermediate level because they have learnt English since they were in the elementary schools. Harmer (2007: 18) states that in this level the students experience "plateau effect" which means that they don't improve much or faster. These challenge the teachers to find ways to attract and encourage the students (Lesiak, 2015). Wilson and Horch (2002: 59) suggest that giving adolescents freedom to choose and make lessons they interest will engage them to learn as they need to show their independence. The use of mobile technology for teaching adolescence is an excellent idea because they are the dominant users of mobile technology. Hyland (2009: 62) writes that the development of technology demands writer teachers to look for the best ways to support the students word processing,

\subsection{Activities for Teaching EFL Writing}

Before presenting the strategies of teaching writing, it is important to review the general process of writing. White and Arndt (1991) in Harmer (2002: 258) list the process of writing are drafting, structuring, reviewing, focusing, and generating ideas and evaluation. While O'Malley and Pierce (96:138) divides the writing process into three steps, prewriting, writing, and post writing. Sample activities in each steps are written by Richards (2015: 496-497) as follow:

1. Prewriting Activities: journals, brainstorming, free association, values clarification, word mapping, ranking activities, quick writing, information gathering. 
2. Writing Activities (Drafting): strategic questioning, timed-focus writing, elaboration exercise, reduction exercise, jumbled paragraph, jumbled essay, writing thesis statements, quick writing, mind mapping, and group drafting.

3. Post Activities (Revising): peer feedback, group correction, rewriting, revising, teacher feedback, checklist.

Other writing activities based on the nature and the organization of the texts include labeling, reordering, comparing, analyzing, correcting, identifying, rewriting, completing, paralleling, and practicing (Richard, 2015: 499).

The writing practices in the classroom are identified into several types. Brown (2001: 343-346) mentions types of classroom writing performance: imitative writing, intensive writing, self-writing, and display writing, and real writing. The principles for designing writing techniques are incorporate practices of "good writer", blanace process and product, account for cultural/literary background, connect reading and writing, provide as much authentic writing as possible, and frame the technique in terms of pre-writing, drafting, and revising stages (Brown, 2001: $346-348$ ).

\subsection{Writing Competences in Indonesian High Schools Syllabus}

English subjects taught in Indonesian senior high schools curriculum in Indonesia used text-based syllabus. Text-based syllabus is categorized into mixed syllabus (Feez and Joyce, 2002: 3). Mixed Syllabus integrates the elements of a range of syllabus types e.g. lexical items, grammatical structures, topics, situations, functions and notions, learning activities and tasks. Burns (2012: 141) “... the key aspect of text-based teaching is authentic language as it is used by speakers and writers in the various contexts of everyday life." She added that this text-based approach is used in a number of areas such as in Singapore and Australia.

Text Types Writing in English Lesson in Indonesian Senior High School

(MOEC, 2013: 66-71)

\begin{tabular}{|c|l|l|}
\hline Grade & $\begin{array}{c}\text { Text Types to be } \\
\text { Written }\end{array}$ & \\
\hline $\mathrm{X}$ & Explanation Text & $\begin{array}{l}\text { Problems related to natural environment such as flood, tsunami, earthquake. } \\
\text { Problems related to social environment such as poverty, brawl, stupidity. }\end{array}$ \\
\cline { 2 - 4 } & Hortatory Text & Solutions to the Problems related to natural and social environment. \\
\hline \multirow{2}{*}{ XI } & Discussion Text & Solutions to the Problems related to natural and social environment. \\
\cline { 2 - 3 } & Description Text & Introducing Indonesian history, art/culture, and tourism to international world. \\
\cline { 2 - 3 } & Procedure Text & Introducing Indonesian history, art/culture, and tourism to international world. \\
\cline { 2 - 3 } & Narrative Text & Introducing Indonesian history, art/culture, and tourism to international world. \\
\hline \multirow{2}{*}{ XII } & Report Text & Local and Foreign history, art/culture, and tourism. \\
\cline { 2 - 3 } & Review Text & Local and Foreign history, art/culture, and tourism. \\
\hline
\end{tabular}

\section{DISCUSSIONS}

Before using whatsApp for teaching and learning writing, there are three important classroom preparation activities. First, creating whatsApp group. The name of the group and the icon are set together in the class. The students in turns in a regular time (every day/every two days/every week) update thegroup icon using motivating picture and English words/phrases. Second, setting up rules for example every student should be active in posting and texting, using English all the time, using polite and constructive language, regular check the WhatsApp. Third, building a positive attitude to the technology and being familiar with the application. Becoming familiar to the technology and the group leads the development of online sense community which can help the students feel free to express (text) ideas. As a result, good rapport between the students and teachers is developing which lead to better learning atmosphere (Khubyari, 2016). By the time both students and teacherbecome familiarwith the whatsApp and feel comfortable to communicate using the app, the activities can be started.

The activities are presented based on Richard's threewriting steps: prewriting activities, writing activities, and post writing activities. The activities are conducted using WhatsApp group and outside the class. The writer provides three techniques of activities. 
Technique 1. Brainstorm - Group Drafting - Teacher Feedback

Context:

Grade: X (15-16 years old)

Goal: Writing Hortatory Text

Starter: Video / Picture about flood in Jakarta

Mode: Classroom Group Discussion

Pre-writing Activity:

The teacher shares a picture / a video about flood happened in Jakarta. Then invites the students to comment and express their feeling about the disaster. The teacher continues asking the students to think critically why it happened and asking "if question": If you were the governor, what would you do to minimize flood victims? The students brainstorm and texts their ideas in the WhatsApp for two days. This "if question" is type of brainstorming and information gathering activities (Richard, 2015: 496) and is appropriate to adolescents who start growing to be critical and independent (Wilson and Horch, 2002: 59).In the next day, the teacher shares the outline template for hortatory text and invites the students to wrap the ideas appears in the WhatsApp chat.

Writing Activity:

The students do group drafting (Richard, 2015: 496). They draft by completing the template and work like a snowball. One student drafts and shares, the other students complete and share again.

Post-Writing Activity:

The teacher gives feedback to the students writing by making use of recording (voice). So the students can listen to the teacher's voice giving comment about their writing.

\section{Technique 2. Starter - Quick Writing - Peer Feedback}

Context:

Grade: XI (16-17 years old)

Goal: Writing Narrative Text

Starter: emoji (emoticons)

Mode: Pair work

Pre-Writing Activity:

The students work in pair using their personal WhatsApp. Student A shares 5 emoticons; students B write very short stories explaining the emoticons. This activity engages the adolescent learners as the teacher gives the students freedom to choose their desired topics (Harmer, 2007: 15).

Writing Activity:

Both students A and B develop the story with the given generic structure of narrative text shared by the teacher (document sharing) in the WhatsApp group.

Post-Writing Activity:

One of the pair (A/B) shares their final story to the WhatsApp group. The teacher and other students give comment (and rating) to the story.

\section{Technique 3. Information Gathering - Elaboration Exercise - Checklist}

Context:

Grade: XII (17-18 years old)

Goal: Writing Review Text

Starter: Share Links / Documents

Mode: Group work (4-5)

Pre-Writing Activity: 
The teacher shares local products links or ads to the WhatsApp group. The students create a smaller group to discuss about the product. The students dig and search information about the plus and minus of the product. One of the principles in developing writing techniques is connect reading and writing (Brown, 2001: 347), so giving them texts or links is useful for the students to start generating ideas.

Writing Activity:

The students write a review text to give balance information for the prospective buyers. They work in the smaller group. The teacher helps them by providing thesis statements to be elaborated by the students. Then, the students share the final review text in the class WhatsApp group.

Post-Writing Activity:

The teacher gives feedback in a form of checklist. The teacher uses the emoticon to weigh the quality of each given writing aspect.

\section{Conclusion}

The cheap and flexible WhatsApp brings potentials to help the English writing learning. The three techniques presented optimize the features in the WhatsApp: share audio, video, picture, links, document, create groups, and text. The presented models aresuited to the principles of teaching writing (Brown, 2001, 346 - 348; Richard, 2015: 496- 497). While this works as a preliminary study, the effectiveness of the techniques should be known from the further empirical trial.

\section{ACKNOWLEDGEMENT}

This paper is part of a project in Developing EFL Writing Materials using MALL and is funded by the Ministry of Higher Education of Indonesia through the Scheme of "Hibah Bersaing 2016" with Project No. : PHB-031/SP3/III/2016.

\section{REFERENCES}

Brown, H Douglas. 2001. Teaching by Principles: An Interactive Approach to Language Pedagogy. NY: Pearson Education.

Burns, Ann. 2012. Text-Based Teaching. In Anne Burns and Jack C. Richards (Eds). The Cambridge Guide to The Pedagogy and Practice in Second Language Teaching (pp 140-148). New York: Cambridge University Press.

Chinnery, Geroge M. 2006. Emerging Technologies: Going to the MALL: Mobile Assisted Language Learning. Language Learning \& Technology. 10 (1), 9 - 16

Cohavi, A. 2013. How did WhatsApp became the strongest social network? Calcalist. (online) http://wwwcalcalist.co.il/local/articles/0,7340,L-3593840,00.html (10 May 2016)

Danesh, Ardeshir and Mehdi Amiri. 2015. Mobile Applications on High School Students' Motivation. Inernational Research Jornal of Applied and Basic Sciences. 9 (8), 1360 - 1367

Fattah, Said Fathy El Said Abdul. 2015. The Effectiveness of Using WhatsApp Messenger as One of Mobile Learning Techniques to Develop Students' Writing Skills. Journal of Education and Practice. 6 (32), 115 - 127.

Feez, Susan and Helen Joyce. 2002. Text-Based Syllabus Design. NSW: AMES.

Harmer, Jeremy. 2002. The Practice of English Language Teaching. England: Longman.

Harmer, Jeremy. 2007. How to Teach English. England: Pearson Education.

Hazaea, Abduljalil Nasr and Alzubi, Ali Abbas. 2016. The Effectiveness of Using Mobile on EFL Learners' Reading Practices in Najran University. English Language Teaching. 9 (5), 8 - 21

Hyland, Ken. 2009. Teaching and Researching Writing. Great Britain: Pearson Education Limited.

Khubyari, Leila. 2016. Rapport in EFL Classroom with Mobile Application in Everyday Context. International Journal of English Language Education. 4 (1), 123 - 137.

Kukulska-Hulme, A\& Shield, L. 2008. An Overview of Mobile Assisted Language Learning: from Content delivery to supported collaboration and interaction. ReCALL. 20, $271-289$.

Lesiak, Karolina. 2015. Teaching English to Adolescents. World Scientific News.(1), 246 - 260 
MOEC. 2013. Kompetensi Dasar Sekolah Menengah Atas (SMA) / Madrasah Aliyah (MA). Kementrian Pendidikan dan Kebudayaan Indonesia.

Mistar, Izyani binti. 2016. Students' Perception on the Use of WhatsApp as A Learning Tool is ESL Classroom. Journal of Education and Social Science. (4), 96 - 104.

O’Malley, J.Micahel. 1996. Authentic Assessment for Language Learners. USA: Addison-Wesley Publishing.

Richard, Jack C.. 2015. Key Issues in Language Teaching. UK: Cambridge University Press.

Sa'aleek, Atef Odeh Abu. 2014. The Review of Emerging Technologies. Asian Journal of Education and e-Learning. 2 (06), $469-475$

Sussex, Ronald. 2012. Text Input and Editing as A Bottleneck in Mobile Devices for Language Learning. In Felicia Zhang (Eds). Computer-Enhanced and Mobile Assisted Language Learning: Emerging Issues and Trends. USA: IGI Global.

Wilson, Lucinda M. and Hadley Wilson Horch. 2002. Implications off Brain Research for Teaching Young Adolescents. Middle School Journal. 34 (1), 57 - 60

\section{AUTHORS' BIOGRAPHY}

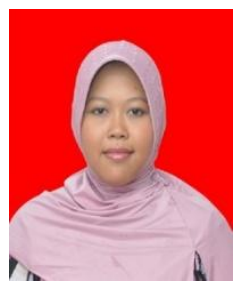

Ani Susanti, is a teacher educator and works in Ahmad Dahlan University, Indonesia in English Education Department. She has been teaching English for 15 years, and had experienced as English teacher at senior high school. Her research interest deals with the teaching of EFL writing, materials development, and educational technology. Currently she is working with English teachers in Yogyakarta to develop techniques and supplementary teaching materials for English mobile/blended learning.

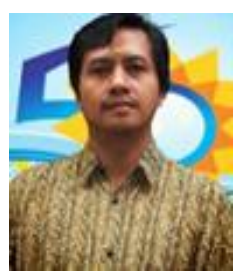

Ali Tarmuji, is a senior lecturer at Universitas Ahmad Dahlan, Yogyakarta, Indonesia. He works in Informatics Engineering Department. His specializations are related to the area of informatics system, web programming, and software engineering. Besides, he is interested in the use of technology in education, experienced e-learning, and has conducted some training for teachers/lecturers to use collaborative tools for e-learning. 